\title{
Prediction of ozone effects on net ecosystem production of Norway spruce forest
}

\author{
Stanislav Juráň ${ }^{(1)}$, \\ Magda Edwards-Jonášová (1), \\ Pavel Cudlín (1), \\ Miloš Zapletal ${ }^{(1-2)}$, \\ Ladislav Šigut ${ }^{(1)}$, \\ John Grace ${ }^{(1-3)}$, \\ Otmar Urban ${ }^{(1)}$
}

\begin{abstract}
Future ground-level concentrations of phytotoxic ozone are projected to grow in the Northern Hemisphere, at a rate depending on emission scenarios. We explored the likely changes in net ecosystem production (NEP) due to the increasing concentration of tropospheric ozone by applying a Generalized Additive Mixed Model based on measurements of ozone concentration $\left(\left[\mathrm{O}_{3}\right]\right)$ and stomatal ozone flux $\left(\mathrm{FsO}_{3}\right)$, at a mountainous Norway spruce forest in the Czech Republic, Central Europe. A dataset covering the growing period (MayAugust 2009) was examined in this case study. A predictive model based on $\mathrm{FsO}_{3}$ was found to be marginally more accurate than a model using $\left[\mathrm{O}_{3}\right]$ alone for prediction of the course of NEP when compared to NEP measured by the eddy covariance technique. Both higher $\left[\mathrm{O}_{3}\right]$ and $\mathrm{FsO}_{3}$ were found to reduce NEP. NEP simulated at low, pre-industrial $\mathrm{FsO}_{3}\left(0.5 \mathrm{nmol} \mathrm{m} \mathrm{m}^{-2} \mathrm{~s}^{-1}\right)$ was higher by $24.8 \%$ as compared to NEP assessed at current rates of $\mathrm{FsO}_{3}\left(8.32 \mathrm{nmol} \mathrm{m}^{-2} \mathrm{~s}^{-1}\right)$. However, NEP simulated at high $\mathrm{FsO}_{3}\left(17 \mathrm{nmol} \mathrm{m}^{-2} \mathrm{~s}^{-1}\right)$, likely in the future, was reduced by $14.1 \%$ as compared to NEP values at current $\mathrm{FsO}_{3}$. The interaction between environmental factors and stomatal conductance is discussed in this paper.
\end{abstract}

\section{Keywords: Carbon, $\mathrm{CO}_{2}$ Assimilation, Model, Stomatal Ozone Flux}

$\left[\mathrm{O}_{3}\right]$ has been increasing over the last decade (Paoletti et al. 2014).

Recent studies at different hierarchical levels have shown that $\mathrm{O}_{3}$ reduces photosynthetic carbon assimilation and changes carbon allocation in trees and forest ecosystems (Wittig et al. 2009, Sicard et al. 2016). It has been demonstrated that $\mathrm{O}_{3}$ alters the source-sink balance in plants, resulting initially in carbon retention in shoots and decreased carbon allocation in below ground biomass (reviewed by Andersen 2003). Rising $\left[\mathrm{O}_{3}\right.$ ] thus has a significant potential to affect terrestrial carbon sinks and regional hydrology (Wittig et al. 2009, Sun et al. 2012). Most of the studies were, however, conducted on seedlings or juvenile trees and the assessment of the $\mathrm{O}_{3}$ impact on mature trees is still at an early stage (Zapletal et al. 2011, 2012, Fares et al. 2013). Accordingly, there is an increasing $\square$ (1) Global Change Research Institute CAS, Belidla 986/4a, 60300 Brno (Czech Republic); (2) Silesian University in Opava, Faculty of Philosophy and Science, Masarykova 37, 74601 Opava (Czech Republic); (3) University of Edinburgh, School of GeoSciences, Crew Bldg, Kings Bldgs, Alexander Crum Brown Rd, Edinburgh EH9 3FF, Midlothian (United Kingdom)

@ Stanislav Juráň (juran.s@czechglobe.cz)

Received: Apr 04, 2018 - Accepted: Aug 27, 2018

Citation: Juráň S, Edwards-Jonášová M, Cudlín P, Zapletal M, Šigut L, Grace J, Urban $O$ (2018). Prediction of ozone effects on net ecosystem production of Norway spruce forest. iForest 11: 743-750. - doi: 10.3832/ifor2805-011 [online 2018-11-15]

Communicated by: Silvano Fares demand for long-term studies conducted under natural, ecologically relevant conditions (Fares et al. 2018).

To quantify the detrimental dose of $\mathrm{O}_{3}$ on vegetation, several indices have been established: AOT40 (accumulated exposure over a threshold of $40 \mathrm{ppbv}$ ) and $\mathrm{POD}_{\mathrm{y}}$ (accumulated ozone flux above a given flux threshold $\left.y\left[\mathrm{nmol} \mathrm{m}^{-2} \mathrm{~s}^{-1}\right]\right)$. Critical levels are assessed as an estimation above which detrimental effects may occur. The magnitude of both indices depends on species, environmental conditions and the capacity of plant defence mechanisms (Musselman \& Massman 1998). Verryckt et al. (2017) reported no impact of ambient $\left[\mathrm{O}_{3}\right]$ on carbon uptake in sub-urban mature pine forest in the vicinity of Antwerp city, Belgium, although the critical levels for both AOT40 and $\mathrm{POD}_{1}$ indices were exceeded. Similarly, an ambient $\left[\mathrm{O}_{3}\right]$ of 50 ppbv (mean value) had no effect on leaf injury in black cherry and red maple seedlings during the period of April-August. While visible symptoms of foliar injury were observed under doubled $\left[\mathrm{O}_{3}\right]$ (Samuelson 1994), no visible damages of leaves nor reduction in $\mathrm{CO}_{2}$ uptake were observed in poplar plantation at a cumulative stomatal $\mathrm{O}_{3}$ uptake of $25-27 \mathrm{mmol} \mathrm{m}^{-2}$ (Zona et al. 2014).

Contrary to these findings, growth decreased by $6.6 \%$ in Swiss forests during the period 1991-2011, particularly in European beech and Norway spruce (Braun et al. 2014), and this decline was ascribed to rising $\left[\mathrm{O}_{3}\right]$. Similarly, Gross Primary Production (GPP) was reduced by $4-8 \%$ on average in eastern US vegetation peaking up to 11- 
$17 \%$ during an occurrence of high $\mathrm{O}_{3}$ episodes (Yue \& Unger 2014). Only a limited effect of $\mathrm{O}_{3}$ on photosynthesis was observed in the broad-leaved Harvard forest (Yue et al. 2016). Norway spruce (Picea $a b$ ies Karst.), a wide-spread tree species of the temperate zone and especially Central Europe, has previously been described as an ozone sensitive tree species (Zapletal et al. 2011). Subramanian et al. (2015), among others, reported a decrease in photosynthetic carbon assimilation of $4.3-15.5 \%$ due to an exposure to high $\left[\mathrm{O}_{3}\right]$. As most studies were conducted on seedlings under controlled conditions (Skärby et al. 1998), estimation and quantification of $\mathrm{O}_{3}$ effects at the ecosystem scale under field conditions received only limited attention.

In the present study, we attempted to quantify the effect of $\mathrm{O}_{3}$ on Net Ecosystem Production (NEP), defined as the difference between ecosystem-level photosynthetic uptake of $\mathrm{CO}_{2}$ and ecosystem respiratory loss of $\mathrm{CO}_{2}$. Our attention was focussed on a mountainous spruce forest in the Czech Republic. NEP values measured by eddy covariance were compared to those estimated by the Generalized Additive Mixed Model (GAMM). We tested the efficacy of $\left[\mathrm{O}_{3}\right]$ - and stomatal ozone flux $\left(\mathrm{FsO}_{3}\right.$ )-based $\mathrm{GAMM}$ models to predict diurnal and seasonal changes in NEP. To determine $\mathrm{O}_{3}$ effects, NEP was calculated in a simulation model at low, pre-industrial $\left[\mathrm{O}_{3}\right]$ (12 ppbv) and $\mathrm{FsO}_{3}\left(0.5 \mathrm{nmol} \mathrm{m}^{-2} \mathrm{~s}^{-1}\right)$ as well as at high $\left[\mathrm{O}_{3}\right](80 \mathrm{ppbv})$ and $\mathrm{FsO}_{3}(17 \mathrm{nmol}$ $\left.\mathrm{m}^{-2} \mathrm{~s}^{-1}\right)$ expected at the end of the century (Meehl et al. 2007, Cooper et al. 2014). We hypothesized that tropospheric ozone reduces NEP in Norway spruce forest. To test this hypothesis, we investigated effects of $\left[\mathrm{O}_{3}\right]$ and $\mathrm{FsO}_{3}$ on NEP during four representative days of the main growing season differing in degree of cloudiness and thus in daily maxima of solar radiation intensity, air temperature, and vapour pressure de- ficit. These representative days also covered seasonal course in NEP and enabled thus to model effects of $\left[\mathrm{O}_{3}\right]$ and $\mathrm{FsO}_{3}$ on NEP throughout the growing season (MayAugust).

\section{Material and methods}

\section{Site description}

The forest stand is located at the Bílý Krríž experimental research site within the Beskydy Mountains in the north-east of the Czech Republic ( $49^{\circ} 30^{\prime} \mathrm{N}, 18^{\circ} 32^{\prime} \mathrm{E}$; $875^{-}$ $908 \mathrm{~m}$ a.s.l.). The experimental research site forms part of several international research networks and infrastructures: CzeCOS (Czech Carbon Observation System), ICOS (Integrated Carbon Observation System), and AnaEE (Analysis and Experimentation on Ecosystems). The forest stand (99\% Picea abies and 1\% Abies alba) had been established in 1981 by row planting of 4-year-old Norway spruce seedlings. Mean stand slope is $13^{\circ}$ and exposure is to the south. In 2009, the year of investigation, the average stand height was $13 \mathrm{~m}$, tree density was 1420 trees ha ${ }^{-1}$, average stem diameter at breast height was 15.9 $\mathrm{cm}$, and leaf area index based on hemispherical photographs was $9.6 \mathrm{~m}^{2} \mathrm{~m}^{-2}$.

The area has a moderately cool (mean air temperature $6.8^{\circ} \mathrm{C}$ ) and humid (mean relative air humidity $84 \%$ ) climate with high annual precipitation (mean annual precipitation $1318 \mathrm{~mm}$; years 1998-2009). Due to an even distribution of precipitation over the year, values of soil volumetric water content remain high during the growing season ranging between 20 and 30\% irrespective of sky conditions. The region is characterized by low concentrations of nitrogen oxides (below $10 \mathrm{ppbv}$ ) and high $\left[\mathrm{O}_{3}\right]$, exceeding 80 ppbv during summer months (Zapletal et al. 2011). Diurnal courses of selected environmental variables, including diurnal changes in $\left[\mathrm{O}_{3}\right]$, for representative days are shown at Fig. 1.

\section{Measurement of environmental variables}

The measurements were conducted from May 28 to September 30, 2009, during the daytime (06:00-18:00 GMT+1) to cover the periods characterized by well-developed turbulent mixing. A meteorological mast (36 $\mathrm{m}$ tall) situated within the studied stand was equipped with a set of meteorological sensors and an eddy covariance system. Air temperature (Tair) and relative air humidity (RH) were measured by an EMS33 Rotro ${ }^{\oplus}$ sensor (EMS, Brno, Czech Republic). These variables were used to calculate the values of vapour pressure deficit (VPD) according to the formula (eqn. 1):

$$
V P D=\frac{100-R H}{100} \cdot 610.7^{\frac{7.5 T \text { air }}{237.3+T \text { air }}}
$$

The barometers PTB110 ${ }^{\circledR}$ (Vaisala, Vantaa, Finland) and SPA $511 \quad \mathrm{~B}_{5} \mathrm{UB}^{\circledR}$ (CRESSTO, Roznov pod Radhostem, (zech Republic) were used to measure air pressure. Global radiation (GR) was measured by a pyranometer $\mathrm{CM}^{\circledR} \mathrm{B}^{\circledast}$ (Kipp \& Zonen, Delft, Netherlands). The 2D ultrasonic anemometer 50.5 (Met One Instruments, Grants Pass, OR, USA) was used for the measurement of horizontal wind speed. All standard meteorological measurements were made on a vertical profile at heights of 2,7 , $10,11.5,12.25,13,13.5,14,15,17,21$, and $28 \mathrm{~m}$ above the soil surface. The signals from all sensors were recorded every $30 \mathrm{~s}$ and stored as half-hourly averages using a data logger (Delta- $T^{\oplus}$, Burwell, Cambridgeshire, UK). In addition, precipitation was recorded by a precipitation gauge 386C (Met One Instruments, Grants Pass, OR, USA).

\section{Estimation of $\mathrm{CO}_{2}$ and $\mathrm{O}_{3}$ fluxes}

An eddy covariance system was used to measure the $\mathrm{CO}_{2}$ and water vapour fluxes between the forest stand and the atmos-

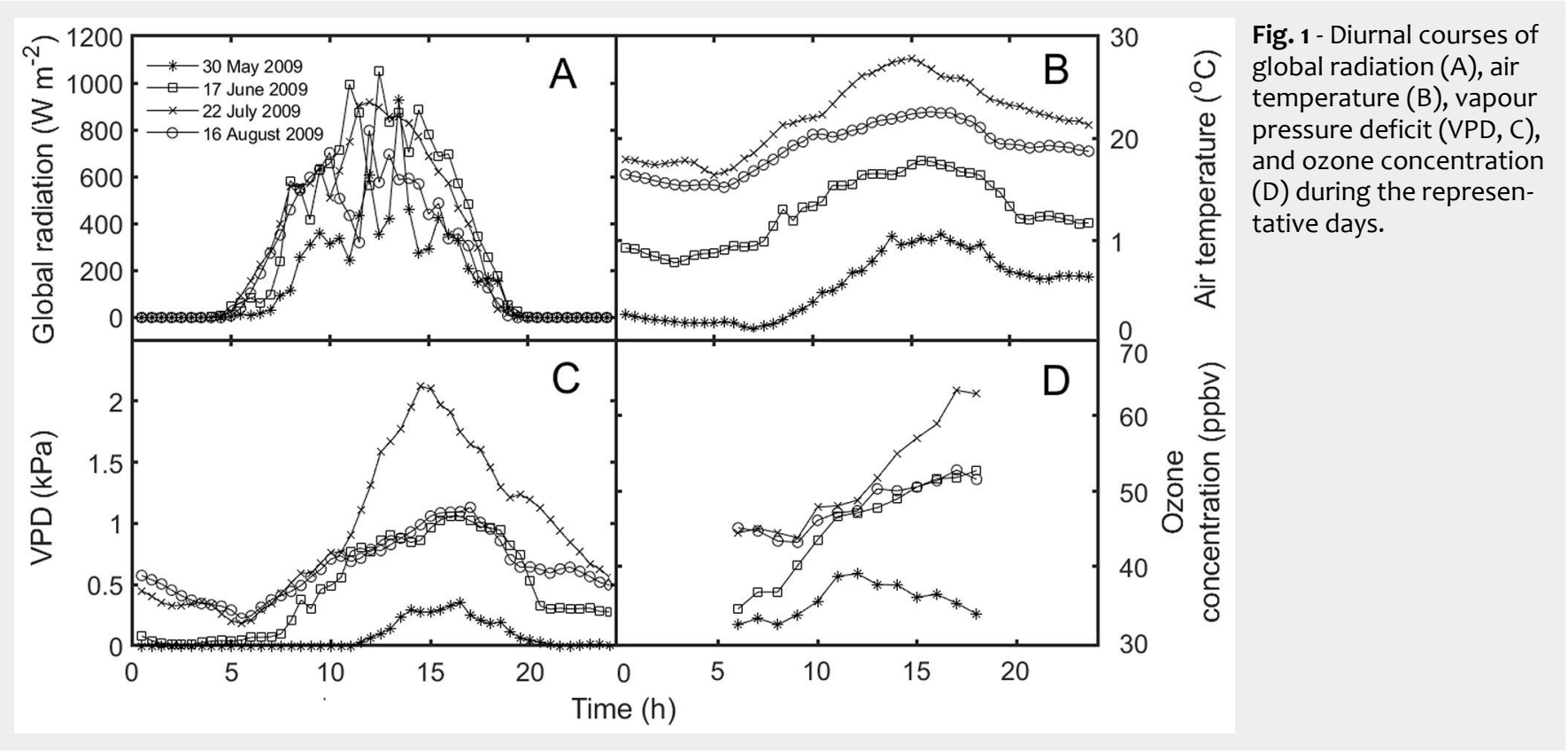


phere. The system consisted of a Gill R3 ${ }^{\circledR}$ ultrasonic anemometer (Gill Instruments, Hampshire, UK) and an enclosed-path infrared gas analyser $\mathrm{LI}-7200^{\circledR}$ (LI-COR Biosciences, Lincoln, NE, USA) placed $18 \mathrm{~m}$ above the soil surface. The post-processing of high frequency data $(20 \mathrm{~Hz})$ was performed by EddyPro ${ }^{\circledR}$ software (LI-COR Biosciences, USA) according to recent recommendations (Aubinet et al. 2012) and expressed as half-hourly estimates. This procedure included spike removal and quality check of the raw signals, rotation of wind velocity components into the planar fit coordinate system, and spectral corrections of computed fluxes. The missing and excluded data, based on the quality checking scheme, were gap-filled by the marginal distribution sampling method according to Reichstein et al. (2005). Sign convention was adopted as follows: positive values represent $\mathrm{CO}_{2}$ uptake, thus enabling convenient modelling of NEP as a general nonrectangular hyperbolic function of incident GR (Urban et al. 2012).

$\left[\mathrm{O}_{3}\right]$ was measured at 5, 15, and $25 \mathrm{~m}$ above the soil surface using slow-response $\mathrm{O}_{3}$ analysers $\mathrm{O}_{3} 41 \mathrm{M}^{\circledast}$ (Environment S.A., Poissy, France). The signals from all $\mathrm{O}_{3}$ analysers were recorded as half-hourly averages.

Stomatal ozone flux $\left(\mathrm{FsO}_{3}\right)$ to the Norway spruce forest was calculated according to Cieslik (2004 - eqn. 2)

$$
\mathrm{FsO}_{3}=\frac{R_{c}}{\left[R_{a}(z)+R_{b}+R_{c}\right] R_{\text {sto }}} \cdot c(z)
$$

where $c(z)$ is $\mathrm{O}_{3}$ concentration at a height $z$ $=2 \mathrm{~m}$ above the canopy, $R_{\mathrm{a}}$ is the aerodynamic resistance for the turbulent layer, $R_{b}$ is the laminar layer resistance for the quasilaminar layer, and $R_{c}$ is the surface or canopy resistance of the receptor. $R_{c}$ was calculated as (eqn. 3):

$$
R_{c}=\left(\frac{L A I}{R_{\text {sto }}}+\frac{S A I}{R_{\text {ext }}}+\frac{1}{R_{\text {inc }}+R_{\text {soil }}}\right)^{-1}
$$

where $R_{\text {sto }}$ is the land-cover specific needle stomatal resistance to $\mathrm{O}_{3}$ uptake, $R_{\text {ext }}$ is the resistance of the external plant parts to uptake or destruction of $\mathrm{O}_{3}, R_{\text {inc }}$ is the landcover specific in-canopy aerodynamic resistance to transport of $\mathrm{O}_{3}$ towards the soil and lower parts of the canopy, $R_{\text {soil }}$ is the soil resistance to destruction or absorption of $\mathrm{O}_{3}$ at the ground surface, $\mathrm{LAl}$ is leaf area index, and SAI is a surface area index set equal to $L A l$ in the growing season.

Stomatal resistance component $R_{\text {sto }}$ was calculated as described in Emberson et al. (2000 - eqn. 4):

$$
\begin{aligned}
R_{\text {sto }}= & g_{\text {max }} \cdot g_{\text {phen }} \cdot \\
& \cdot \max \left\{g_{\text {min }},\left(g_{\text {light }} \cdot g_{\text {temp }} \cdot g_{V P D} \cdot g_{\text {SWP }}\right)\right\}^{-1}
\end{aligned}
$$

where $g_{\max }$ is the average maximum stomatal conductance of Picea abies to ozone ( $\mathrm{nmol} \mathrm{O} \mathrm{O}_{3} \mathrm{~m}^{-1}$ ) expressed on total needle surface area. The parameters $g_{\text {phen, }} g_{\text {light }}$, $g_{\text {temp }}, g_{v P D}$, and $g_{\text {sWP }}$ are expressed in relative terms between 0 and 1 , and represent the
Tab. 1 - Meteorological variables of the period May 28-September 30, 2009. $\left[\mathrm{O}_{3}\right]$ : ozone concentration; $\left(\mathrm{FsO}_{3}\right)$ : stomatal ozone flux; (VPD): vapour pressure deficit; (GR): global radiation; (RH): relative air humidity; (Tair): air temperature; (Tr): transpiration; (NEP): net ecosystem production: (SD): standard deviation.

\begin{tabular}{llcrc}
\hline Variable & Unit & Mean & \multicolumn{1}{c}{ SD } & Range \\
\hline $\mathrm{NEP}$ & $\mu \mathrm{mol} \mathrm{m}^{-2} \mathrm{~s}^{-1}$ & 12.1 & 9.2 & $-7.9-31.7$ \\
\hline$\left[\mathrm{O}_{3}\right]$ & $\mathrm{ppbv}$ & 42.9 & 11.2 & $12.0-79.5$ \\
$\mathrm{FsO}_{3}$ & $\mathrm{nmol} \mathrm{m}^{-2} \mathrm{~s}^{-1}$ & 8.3 & 3.6 & $0.072-17.6$ \\
\hline $\mathrm{GR}$ & $\mathrm{W} \mathrm{m}^{-2}$ & 342.3 & 247.4 & $0.86-974$ \\
\hline $\mathrm{Tair}$ & ${ }^{\circ} \mathrm{C}$ & 17.7 & 6.1 & $1.3-33.8$ \\
\hline $\mathrm{RH}$ & $\%$ & 75.2 & 17.3 & $37.6-99.9$ \\
$\mathrm{Tr}$ & $\mathrm{mm} \mathrm{h}$ & 0.0878 & 0.0754 & $0-0.37$ \\
\hline $\mathrm{VPD}$ & $\mathrm{kPa}$ & 0.624 & 0.585 & $0.0006-2.89$ \\
\hline
\end{tabular}

modification of $g_{\max }$ due to phenological changes, light intensity, air temperature, tential, respectively. $g_{\min }$ is the minimum $\mathrm{FsO}_{3}$ that occurs during daylight hours.

The model was applied using environmental variables measured at the experimental station, although soil moisture deficit was estimated as a function of precipitation and daily mean surface temperature according to the principles of water budget. For more details and the site-specific model parameterisation see Zapletal et al. (2011).

\section{Modelling and statistical analyses}

The Generalized Additive Mixed Model (GAMM) was implemented in the "mgcv" package of the R ver. 3.4.0 program (Wood 2017) to assess the dependencies between NEP and its predictors GR, RH, Tair, VPD, and transpiration rate along with $\left[\mathrm{O}_{3}\right]$ and $\mathrm{FsO}_{3}$ (Tab. 1). One-hour averages of all input data were used in GAMM. Only the data of the daytime period (06:00-18:00) when $\mathrm{GR}$ exceeded $10 \mathrm{~W} \mathrm{~m}^{-2}$ were used, so as to exclude periods where turbulence was not well-developed.

All predictors were tested and fitted by a vapor pressure deficit, and soil water po- linear model, in the form of splines as smooth functions and as $1^{\text {st }}$ degree linear interactions. Predictors were centred and, in the case of $G R$ and $R H$, a square root transformation was used. Day of observation and autocorrelation pattern were tested as random factors. The best model was selected based on the AIC criteria and $p$-values. The model was started as one component containing all explanatory variables together with their interactions. By use of REML (Restricted Maximum Likelihood Estimation) the optimal structure of the random component was found. Then, optimal fixed structure using ML (Maximum Likehood) estimation was determined. Within the fixed structure, REML estimation was applied again.

\section{Results}

Microclimate conditions, $\left[\mathrm{O}_{3}\right]$ and $\mathrm{FsO}_{3}$

The mean incoming daily sum of $G R$ was $15.8 \mathrm{MJ} \mathrm{m}^{-2}$, mean Tair was $15.03^{\circ} \mathrm{C}$, RH was $81.5 \%$, and precipitation sum was $388 \mathrm{~mm}$ during the investigated period from May 28 to September 30. Soil volumetric water content remained high during the whole growing season ranging between 20 and

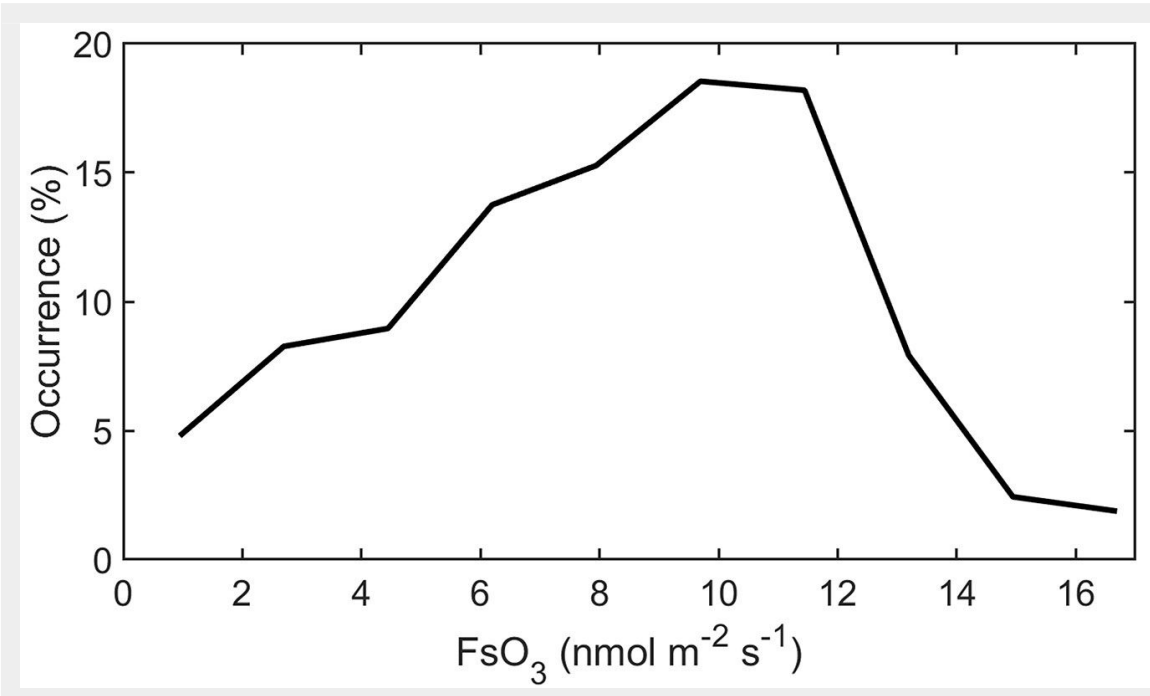

Fig. 2 - Relative occurrence of stomatal ozone flux $\left(\mathrm{FsO}_{3}\right)$ during the sunlight hours modelled for the period May 28-September 30, 2009. 
Tab. 2 - Outputs of Generalized Additive Mixed Model (GAMM) predicting mixed effects of $\left[\mathrm{O}_{3}\right]$ and other selected micrometeorological variables (predictors) on net ecosystem production (NEP). Linear predictors and linear interaction statistics are shown as $t$-values and $p$-values, whereas statistics of predictors used as smooth terms are shown as F-statistics, p-values and Edf. $\times$ indicate interaction. (Edf): estimated degree of freedom, Edf $>1$ indicate nonlinear relationships. $R^{2}$ (adjusted) $=0.948, \mathrm{n}=$ 1440. [ $\mathrm{O}_{3}$ ]: ozone concentration; (VPD): vapour pressure deficit; (GR): global radiation; $(\mathrm{RH})$ : relative air humidity; (Tair): air temperature; (Tr): transpiration (***): $p<0.001$; $(* *): p<0.01 ;(*): p<0.05$.

\begin{tabular}{|c|c|c|c|c|c|}
\hline \multirow{2}{*}{$\begin{array}{l}\text { Predictor/ } \\
\text { Interaction }\end{array}$} & \multicolumn{2}{|c|}{ Goodness of fit } & \multicolumn{3}{|c|}{ Statistics } \\
\hline & $\begin{array}{l}\text { Parametric } \\
\text { estimate }\end{array}$ & Edf & $t$-value & $F$ & $p$-value \\
\hline$\left[\mathrm{O}_{3}\right]$ & -0.042609 & - & 4.655 & - & $3.55 e-06^{* * *}$ \\
\hline VPD & 1.686854 & - & 2.226 & - & $0.026154^{*}$ \\
\hline$\left[\mathrm{O}_{3}\right] \times \mathrm{GR}$ & -0.002573 & - & -3.390 & - & $0.000717^{* * *}$ \\
\hline $\mathrm{GR} \times \mathrm{RH}$ & -0.100322 & - & -6.310 & - & $3.73 e-10^{* * *}$ \\
\hline GR $\times$ Tair & 0.013316 & - & 6.919 & - & $6.84 \mathrm{e}-12^{* * *}$ \\
\hline $\mathrm{GR} \times \mathrm{Tr}$ & -0.476992 & - & -3.499 & - & $0.000481^{* * *}$ \\
\hline$V P D \times G R$ & -0.280066 & - & -8.314 & - & $<2 \mathrm{e}-16^{* * *}$ \\
\hline$s(G R)$ & - & 2.987 & - & 6835.670 & $<2 \mathrm{e}-16^{* * *}$ \\
\hline$s(\mathrm{RH})$ & - & 2.878 & - & 22.424 & $6.5 e-13^{* * *}$ \\
\hline s(Tair) & - & 2.4577 & - & 6.775 & $0.000807^{* * *}$ \\
\hline$s(\operatorname{Tr})$ & - & 2.384 & - & 5.168 & $0.003775^{* *}$ \\
\hline
\end{tabular}

Tab. 3 - Outputs of Generalized Additive Mixed Model (GAMM) predicting mixed effects of stomatal ozone flux $\left(\mathrm{FsO}_{3}\right)$ and other selected micrometeorological variables (predictors) on net ecosystem production (NEP). Linear predictors and linear interaction statistics are shown as $t$-values and $p$-values, whereas statistics of predictors used as smooth terms are shown as F-statistics, $p$-values and Edf. $\times$ indicate interaction. (Edf): estimated degree of freedom; Edf values $>1$ indicate nonlinear relationships. $R^{2}$ (adjusted) $=0.95, \mathrm{n}=1440 .\left(\mathrm{FsO}_{3}\right)$ : stomatal ozone flux; $(\mathrm{VPD})$ : vapour pressure deficit; (GR): global radiation; $(\mathrm{RH})$ : relative air humidity; (Tair): air temperature; (Tr): transpiration; $(* * *): p<0.001 ;(* *): p<0.01 ;(*): p<0.05$.

\begin{tabular}{|c|c|c|c|c|c|}
\hline \multirow{2}{*}{$\begin{array}{l}\text { Predictor/ } \\
\text { Interaction }\end{array}$} & \multicolumn{2}{|c|}{ Goodness of fit } & \multicolumn{3}{|c|}{ Statistics } \\
\hline & $\begin{array}{l}\text { Parametric } \\
\text { estimate }\end{array}$ & Edf & $t$-value & $F$ & $p$-value \\
\hline VPD & 2.301725 & - & 2.850 & - & $0.00443^{* *}$ \\
\hline $\mathrm{GR} \times \mathrm{FsO}_{3}$ & -0.016042 & - & -4.577 & - & $5.14 \mathrm{e}-06^{* * *}$ \\
\hline $\mathrm{GR} \times \mathrm{RH}$ & -0.142519 & - & -7.082 & - & $2.23 e-12^{* * *}$ \\
\hline GR $\times$ Tair & 0.014084 & - & 7.378 & - & $2.73 e-13^{* * *}$ \\
\hline $\mathrm{VPD} \times \mathrm{GR}$ & -0.388303 & - & -9.721 & - & $<2 \mathrm{e}-16^{* * *}$ \\
\hline$s(G R)$ & - & 2.973 & - & 6314.858 & $<2 \mathrm{e}-16^{* * *}$ \\
\hline$s(\mathrm{RH})$ & - & 2.865 & - & 18.079 & $5.99 \mathrm{e}-08^{* * *}$ \\
\hline s(Tair) & - & 2.824 & - & 11.175 & $8.78 \mathrm{e}-07^{* * *}$ \\
\hline $\mathrm{s}\left(\mathrm{FsO}_{3}\right)$ & - & 2.933 & - & 22.547 & $7.77 e-13^{* * *}$ \\
\hline$s(\operatorname{Tr})$ & - & 2.701 & - & 7.112 & $0.000131^{* * *}$ \\
\hline
\end{tabular}

$30 \%$ irrespective of actual sky conditions. Four model days, selected on the base of cloudiness degree (Fig. 1), represent (i) a sunny warm day with high Tair and VPD values (July 22) and (ii) partly-cloudy sky conditions with mild Tair and VPD (June 17 and August 16). (iii) The onset of the growing season (May 30) was characterized by the minimum values of GR, Tair and VPD. These days were also characterized by distinct $\left[\mathrm{O}_{3}\right]$ with daily maxima ranging between 38 and 64 ppbv (Fig. 1D) as well as diurnal courses of $\mathrm{FsO}_{3}$ (Fig. S1 in Supplementary material). The most frequent $\mathrm{FsO}_{3}$ values ranged from 8-12 nmol m$~ m^{-2} \mathrm{~s}^{-1}$ during sunlight hours when the whole dataset is considered (Fig. 2).

\section{GAMM outputs}

The results of GAMM model for NEP prediction including $\left[\mathrm{O}_{3}\right]$ and $\mathrm{FsO}_{3}$ are shown in Tab. 2 and Tab. 3, respectively. Both models include a linear and non-linear part, as illustrated by the Edf parameter, which is presented only in the non-linear part. Only statistically significant predictors are shown. $\left[\mathrm{O}_{3}\right]$ and $\mathrm{VPD}$ variables are shown only in Tab. 2, as their effect on NEP was only linear. Based on the Edf parameter, it was shown that $\mathrm{FsO}_{3}$ had a non-linear effect on NEP (Tab. 3).

Statistically significant $(p<0.01)$ interactions were found between $\left[\mathrm{O}_{3}\right]$ and $\mathrm{GR}$ and between $\mathrm{FsO}_{3}$ and GR (Tab. 2, Tab. 3). Both interactions had negative values of parametric estimate (Tab. 2, Tab. 3) indicating that $\left[\mathrm{O}_{3}\right]$ and $\mathrm{FsO}_{3}$ led to a larger reduction of NEP with increasing GR. For example, natural $\mathrm{FsO}_{3}$ led to a decrease in NEP by $1.07 \mu \mathrm{mol} \mathrm{m}^{-2} \mathrm{~s}^{-1}$, comparing to pre-industrial era, at $G R<300 \mathrm{~W} \mathrm{~m}^{-2}$, whereas this reduction amounted up to $1.59 \mu \mathrm{mol} \mathrm{m} \mathrm{m}^{-2} \mathrm{~s}^{-1}$ (23.6\%) at $\mathrm{GR}>500 \mathrm{~W} \mathrm{~m}^{-2}$. The $\mathrm{FsO}_{3}$ seems to be more tightly linked to ozone-induced decline of NEP than $\left[\mathrm{O}_{3}\right]$ itself, based on explained variance by the models $\left(R^{2}\right)$ and more significant $p$-value for $\mathrm{FsO}_{3}(p=7.77 \mathrm{e}$ $13)$ that $\left[\mathrm{O}_{3}\right](p=3.55 \mathrm{e}-06)$. $\mathrm{GR}$ was identified as the most important driver of NEP, having the most significant $p$ values (Tab. 2, Tab. 3).

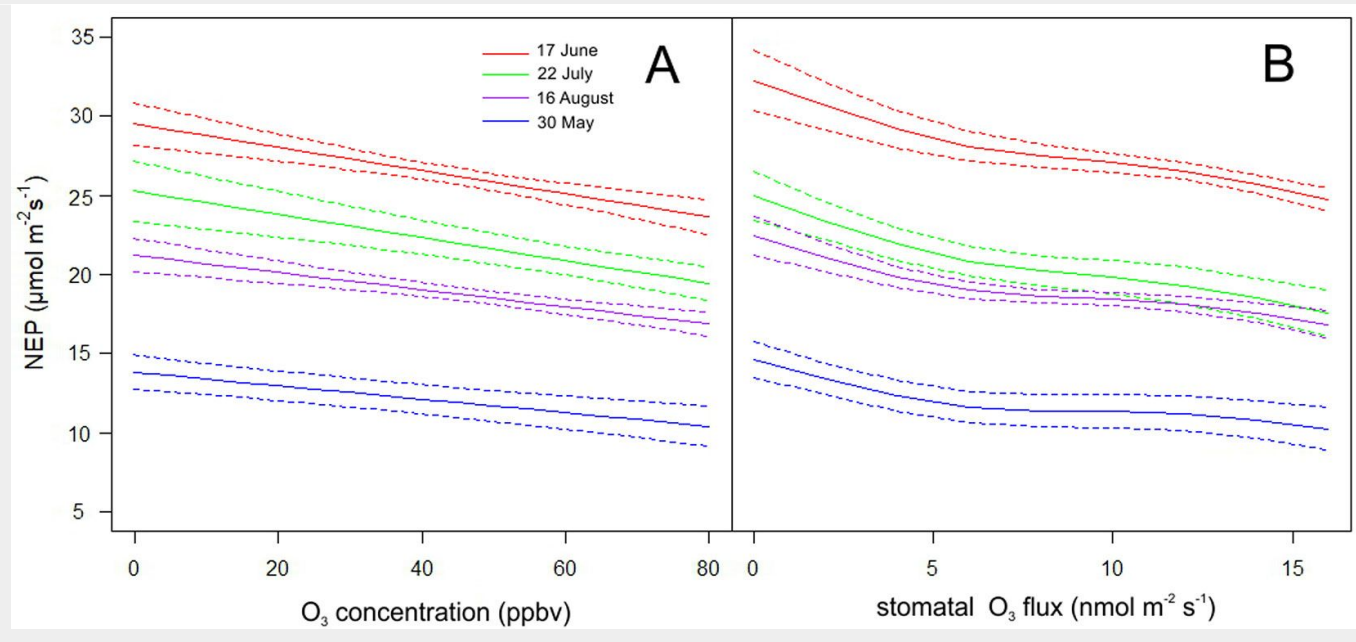

Fig. 3 - Modelled relationships between net ecosystem production (NEP) and ozone concentration (A) and between NEP and stomatal ozone flux (B) for four representative days (full line). Models were applied with fixed predictors (see Tab. 1) measured at 11:00 of these representative days. Dashed lines represent the $95 \%$ confidence interval. 


\section{NEP modelling}

NEP was predicted using $\left[\mathrm{O}_{3}\right]$ (Fig. $3 \mathrm{~A}$ ) and $\mathrm{FsO}_{3}$ (Fig. $3 \mathrm{~B}$ ) values in the range from zero to maximal values determined during the investigated growing season (May-September). Values of other predictors were fixed to values measured at 11:00 of the representative days. Both models predict a decrease in NEP with increasing $\left[\mathrm{O}_{3}\right]$ or increasing $\mathrm{FsO}_{3}$. Among the representative days, the highest decrease of NEP was found on May $30^{\text {th }}$, amounting to $21.6 \%$ (model run with $\left[\mathrm{O}_{3}\right]$ ) and $30.4 \%$ (model run with $\mathrm{FsO}_{3}$ ) when compared NEP at minimum (affected by $12 \mathrm{ppbv}$ and $0.5 \mathrm{nmol} \mathrm{m}^{-2}$ $\mathrm{s}^{-1}$ ) and maximum (affected by $80 \mathrm{ppbv}$ and $17 \mathrm{nmol} \mathrm{m} \mathrm{m}^{-1}$ ) values of $\left[\mathrm{O}_{3}\right]$ and $\mathrm{FsO}_{3}$, respectively. In July 22 , the warmest month, the corresponding decreases were $24.9 \%$ and $28.9 \%$. Diurnal courses of measured and modelled NEP during four representative days of the vegetation season are shown in Fig. 4.

Multi-factorial analysis (Fig. S2 in Supplementary material) revealed that high $\mathrm{FsO}_{3}$ $\left(17 \mathrm{nmol} \mathrm{m} \mathrm{m}^{-2} \mathrm{~s}^{-1}\right)$ has the most significant effect on NEP reduction in summer, while NEP decrease is driven more by GR than $\mathrm{FsO}_{3}$ in spring and autumn. Moreover, VPDinduced stomatal closure was a main factor limiting NEP and stomatal $\mathrm{O}_{3}$ flux in Norway spruce trees throughout the whole growing season. Therefore, a strong relationship between NEP reduction and stomatal conductance, not only the simple $\left[\mathrm{O}_{3}\right]$ outside the leaves, can be suggested.

Taking to the account the whole dataset, the GAMM based calculated NEP was higher by up to $12.4 \%$ at low, preindustrial ozone concentration (12 ppbv) as compared to the measured NEP at the present concentration of $42.9 \pm 11.2$ ppbv (mean \pm SD - Tab. 1). Similarly, the GAMM based on

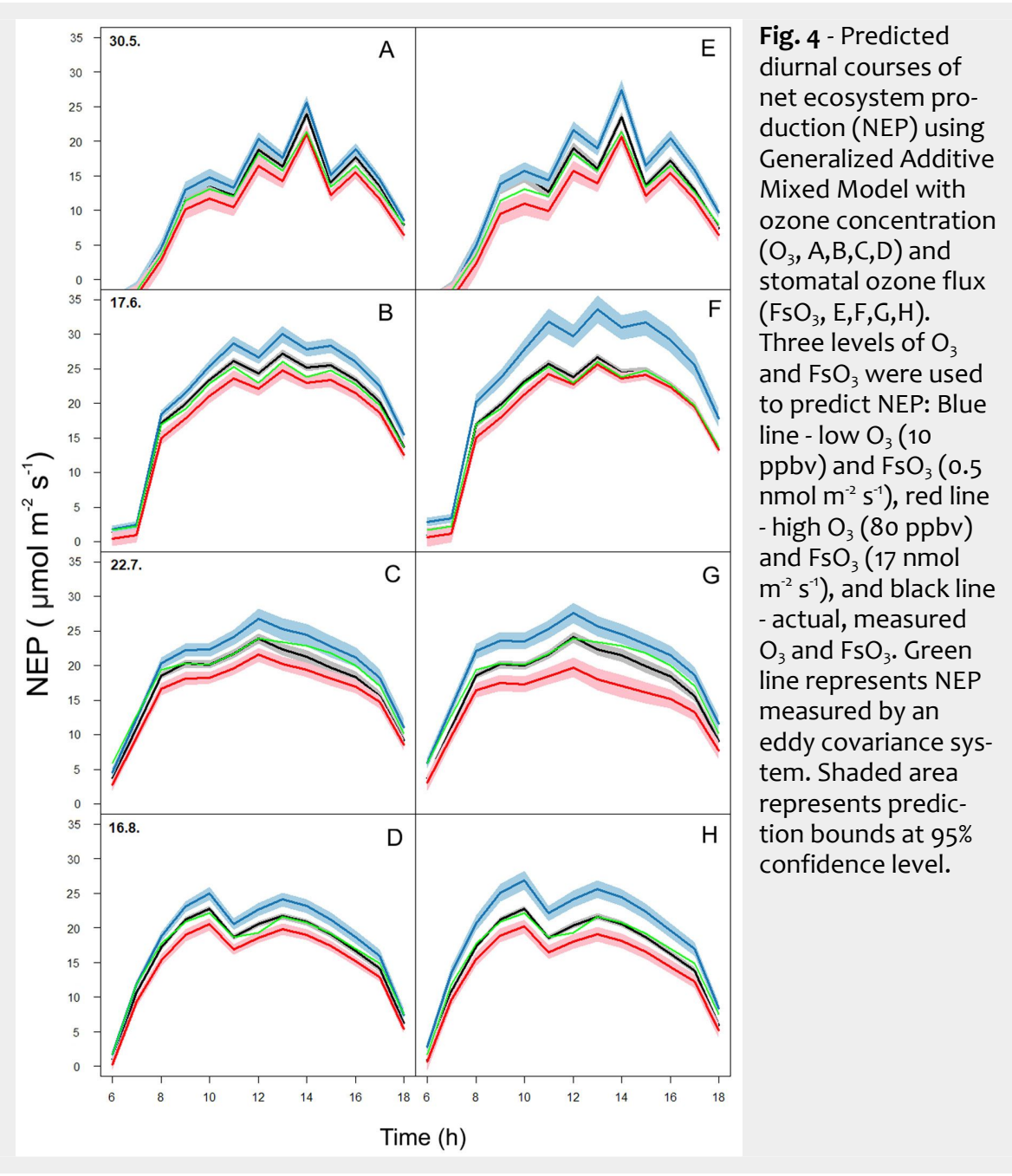

$\mathrm{FsO}_{3}$ revealed NEP to be elevated by up to trast, high $\left[\mathrm{O}_{3}\right]$ ( $80 \mathrm{ppbv}$ ) and high $\mathrm{FsO}_{3}(17$ $24.8 \%$ under the condition of low $\mathrm{FsO}_{3}\left(0.5 \mathrm{nmol} \mathrm{m}^{-2} \mathrm{~s}^{-1}\right)$ were found to lead to a denmol m $\mathrm{m}^{-2}$ ) as compared to actual $\mathrm{FsO}_{3}$ of crease in NEP by $24 \%$ and $38.9 \%$, respec$8.3 \pm 3.7 \mathrm{nmol} \mathrm{m}^{-2} \mathrm{~s}^{-1}$ (mean $\pm \mathrm{SD}$ ). In con- tively as compared to preindustrial NEP val-

Tab. 4 - Mean values of ambient (Amb) ozone concentration ( $\left[\mathrm{O}_{3}\right]$; ppbv) and stomatal ozone flux $\left(\mathrm{FsO}_{3} ; \mathrm{nmol} \mathrm{m}^{-2} \mathrm{~s}^{-1}\right)$, and $\mathrm{Net}$


high, and low $\mathrm{O}_{3}$ ] and $\mathrm{FsO}_{3}$ during the individual months of the growing season and the whole dataset covering May 28-September 30, 2009. $\Delta$ represents percentage difference of predicted NEP to mean NEP measured by an eddy covariance system. (a) values of $\Delta$ represent percentage decrease in NEP induced by high $\mathrm{O}_{3}(80 \mathrm{ppbv})$ and/or $\mathrm{FsO}_{3}\left(17 \mathrm{nmol} \mathrm{m}^{-2} \mathrm{~s}^{-1}\right)$; (b): values of $\Delta$ represent percentage increase in NEP at low $\mathrm{O}_{3}(12 \mathrm{ppbv})$ and/or $\mathrm{FsO}_{3}\left(0.5 \mathrm{nmol} \mathrm{m}^{-2} \mathrm{~s}^{-1}\right)$.

\begin{tabular}{|c|c|c|c|c|c|c|c|}
\hline Months & Conditions & $\mathrm{Amb}\left[\mathrm{O}_{3}\right]$ & $\operatorname{Low}\left[\mathrm{O}_{3}\right]$ & High $\left[\mathrm{O}_{3}\right]$ & $\mathrm{Amb} \mathrm{FsO}_{3}$ & Low $\mathrm{FsO}_{3}$ & High $\mathrm{FsO}_{3}$ \\
\hline \multirow[t]{3}{*}{ May } & {$\left[\mathrm{O}_{3}\right] / \mathrm{FsO}_{3}$} & 36.5 & 12 & 80 & 5.5 & 0.5 & 17 \\
\hline & NEP & 7.9 & 9.6 & 7.2 & 7.9 & 10.8 & 7.2 \\
\hline & $\Delta$ & - & $21.5^{\mathrm{b}}$ & $8.9^{\text {a }}$ & - & $36.7^{\mathrm{b}}$ & $8.9^{a}$ \\
\hline \multirow{3}{*}{ June } & {$\left[\mathrm{O}_{3}\right] / \mathrm{FsO}_{3}$} & 42 & 12 & 80 & 9.1 & 0.5 & 17 \\
\hline & NEP & 10.2 & 12.5 & 9.7 & 10.2 & 14.1 & 7.7 \\
\hline & $\Delta$ & - & $22.5^{\mathrm{b}}$ & $4.9^{a}$ & - & $38.2^{\mathrm{b}}$ & $24.5^{\mathrm{a}}$ \\
\hline \multirow[t]{3}{*}{ July } & {$\left[\mathrm{O}_{3}\right] / \mathrm{FsO}_{3}$} & 46.2 & 12 & 80 & 8.98 & 0.5 & 17 \\
\hline & NEP & 15.3 & 17.2 & 13.8 & 15.3 & 18.7 & 13.5 \\
\hline & $\Delta$ & - & $12.4^{\mathrm{b}}$ & $9.8^{\mathrm{a}}$ & - & $22.2^{b}$ & $11.8^{\mathrm{a}}$ \\
\hline \multirow[t]{3}{*}{ Aug } & {$\left[\mathrm{O}_{3}\right] / \mathrm{FsO}_{3}$} & 45 & 12 & 80 & 8.5 & 0.5 & 17 \\
\hline & NEP & 12.6 & 13.9 & 11 & 12.6 & 15.4 & 10.9 \\
\hline & $\Delta$ & - & $10.3^{b}$ & $12.7^{\mathrm{a}}$ & - & $22.2^{\mathrm{b}}$ & $13.5^{\mathrm{a}}$ \\
\hline \multirow[t]{3}{*}{ Sept } & {$\left[\mathrm{O}_{3}\right] / \mathrm{FsO}_{3}$} & 39.1 & 12 & 80 & 7.2 & 0.5 & 17 \\
\hline & NEP & 10.4 & 10.8 & 8.3 & 10.4 & 12.3 & 8.5 \\
\hline & $\Delta$ & - & 3.8 & 20.2 & - & 18.3 & 18.3 \\
\hline \multirow[t]{3}{*}{ Whole dataset } & {$\left[\mathrm{O}_{3}\right] / \mathrm{FsO}_{3}$} & 42.9 & 12 & 80 & 8.3 & 0.5 & 17 \\
\hline & NEP & 12.1 & 13.6 & 10.7 & 12.1 & 15.1 & 10.4 \\
\hline & $\Delta$ & - & 12.4 & 11.6 & - & 24.8 & 14.1 \\
\hline
\end{tabular}


ues which were unaffected by high $\left[\mathrm{O}_{3}\right] 12 \mathrm{ppbv}$ and high $\left[\mathrm{O}_{3}\right]$ of $80 \mathrm{ppbv}$. and/or $\mathrm{FsO}_{3}$ (Tab. 4).

In addition, we present estimated changes in NEP under the conditions of low/high $\left[\mathrm{O}_{3}\right.$ ] and $\mathrm{FsO}_{3}$ during individual months of the growing season (May-September - Tab. 4). Both models confirmed a high percentage reduction of NEP occurring in spring (May-June), comparing values of current NEP to preindustrial ones, while the $\mathrm{O}_{3}$-induced NEP reduction in September was relatively small. The largest $a b-$ solute reduction occurred, however, in June and July when NEP reaches a seasonal maximum. Contrary to those findings, the largest percentage and absolute NEP reductions predicted at high $\left[\mathrm{O}_{3}\right]$ and $\mathrm{FsO}_{3}$ were found in September whereas the lowest ones in June.

\section{Discussion}

Projections of $\mathrm{O}_{3}$-induced damage are uncertain due to numerous scenarios dealing with different future $\left[\mathrm{O}_{3}\right]$ or $\mathrm{FsO}_{3}$. Ozone in the Northern Hemisphere is projected to increase further by $20-25 \%$ between 2015 and 2050 , and by $40-60 \%$ by 2100 , if current ozone-precursors $\left(\mathrm{CO}_{2}\right.$, volatile organic compounds, $\mathrm{NO}_{x}$ ) emission trends continue (Meehl et al. 2007). Sitch et al. (2007) projected a decrease in NEP by $14-23 \%$ over the period 1901-2100 owing to plant damage caused by $\left[\mathrm{O}_{3}\right]$ with regional reduction peeking up to $30 \%$. However, recent studies suggest $\left[\mathrm{O}_{3}\right]$ decreases on average by o2 ppbv between 2000-2030 years, rising to $10 \mathrm{ppbv}$ in 2100 in north latitudes (Young et al. 2013). Those findings are in accordance with Klingberg et al. (2014), who expected a decrease of $\mathrm{O}_{3}$ precursors, particularly biogenic volatile organic compounds (BVOCs) and nitrogen oxides ( $\mathrm{NO}_{x}$ ), according to RCP4.5 scenario, which should consequently lead to decrease of European vegetation damage. However, extreme periods expected under future climate conditions may lead to episodes with high $\left[\mathrm{O}_{3}\right]$. For example, severe drought conditions in 2003 were associated with high $\left[\mathrm{O}_{3}\right]$ in the Central Europe (Solberg et al. 2008). In relation to regional climate, Beniston (2004) assumed that the year 2003 could be used as an analogy of future dry summer seasons resulting in high emissions of BVOCs and $\mathrm{NO}_{\mathrm{x}}$ (Young et al. 2013), which showed to depend highly on season also at Bílý Kríž (Jurán et al. 2017). Future impacts on ozone concentration across Europe show contradicting results: under RCP8.5 scenario, $\left[\mathrm{O}_{3}\right]$ of temperate coniferous forest could increase by 10.2 ppbv as modelled for coniferous forests at Hengduan Shan, China forests (Fuhrer et al. 2016). On the other hand, a modelling study for the temperate coniferous forest of the Sierra Nevada suggests a decrease in $\left[\mathrm{O}_{3}\right]$ by 6 ppbv from 2000 to 2050 (Fuhrer et al. 2016) in accordance with the $\left[\mathrm{O}_{3}\right]$ decrease by 5 ppbv per decade (Cooper et al. 2014). In our study we have contrasted the $\mathrm{O}_{3}$ effects on NEP at low, pre-industrial $\left[\mathrm{O}_{3}\right]$ of
Numerous studies have shown that elevated $\left[\mathrm{O}_{3}\right]$ generally results in reduced photosynthesis, chlorophyll content and whole-plant growth, decreased stomatal conductance, an altered antioxidant system, accelerated senescence and changes the plant metabolism, although the extent of the effects varies by species, length of exposure, $\left[\mathrm{O}_{3}\right]$ and/or co-occurrence of other stress factors (reviewed in Wallin et al. 2002, Kontunen-Soppela et al. 2007, Hoshika et al. 2018). In accordance with these studies we have found here that both increasing $\left[\mathrm{O}_{3}\right]$ and $\mathrm{FsO}_{3}$ significantly reduced NEP of mature Norway spruce forest grown under natural mountain conditions (Fig. 3). Moreover, our analyses show that the use of $\mathrm{FsO}_{3}$ provides an improved fit to NEP experimental data as compared to the predictions of a merely $\left[\mathrm{O}_{3}\right]$-based GAMM model, particularly under hot summer days (Tab. 4). Differences between the measured and predicted NEP by the model with $\left[\mathrm{O}_{3}\right]$ and $\mathrm{FsO}_{3}$ expressed as a model error amounted to $0.41 \%$ and $0.17 \%$, respectively. The theory behind this is that stomata substantially regulate both $\mathrm{CO}_{2}$ and $\mathrm{O}_{3}$ diffusion into the leaf interior leading thus to a modulation of photosynthetic activity and the magnitude of $\mathrm{O}_{3}$-induced injuries, respectively. We assume that stomata remain open under the conditions of low VPD and sufficient light intensity (Urban et al. 2012). Accordingly, high $\mathrm{FsO}_{3}$ can be expected though ambient $\left[\mathrm{O}_{3}\right]$ is relatively low and can lead to a substantial NEP reduction. On the contrary, conditions of high VPD and/or high temperature may result in a marked closure of stomata. While an ambient $\left[\mathrm{O}_{3}\right]$ is usually high under such conditions, $\mathrm{O}_{3}$-induced reduction of NEP may be depressed due to a low $\mathrm{FsO}_{3}$ into a leaf interior. Therefore, models with high $\mathrm{FsO}_{3}$ may predict higher reduction in NEP than models with high $\left[\mathrm{O}_{3}\right]$ (Fig. 3). Such results imply that not only high $\left[\mathrm{O}_{3}\right]$, but particularly high $\mathrm{FsO}_{3}$ induces injuries on vegetation and reduces carbon assimilation (Matyssek et al. 2007, Fares et al. 2013).

We predicted higher NEP (by $24.6 \%$ on average) at low $\mathrm{FsO}_{3}$ of $0.5 \mathrm{nmol} \mathrm{m} \mathrm{m}^{-2} \mathrm{~s}^{-1}$ as compared to NEP at current $\mathrm{FsO}_{3}$ of $8.32 \pm$ $3.66 \mathrm{nmol} \mathrm{m}^{-2} \mathrm{~s}^{-1}$ with the highest absolute reduction occurring in June and July (Tab. 4). Karlsson (2012) stated that reduction of the living biomass carbon stock caused by the ozone problem among the Central and Northern European countries ranges from $2 \%$ (Norway, Finland) to $32 \%$ in the Czech Republic, when compared to the pre-industrial age. Satellite data over the European continent suggest a decline of photosynthetic carbon uptake ranging between 0.4$30 \%$ due to $\mathrm{O}_{3}$ damage depending on the forest type and location. Highest negative effects of $\mathrm{O}_{3}$ were found in coniferous forests (Proietti et al. 2016). Moreover, these authors identified air temperature, soil water content, and relative air humidity as key predictors of NEP describing more than $81 \%$ of NEP variability. Soil water content was, however, omitted into our model, since soil water content was not a limiting factor in our case study under the wet mountainous conditions. However, air temperature and relative air humidity (ultimately VPD), play significant roles in our model together with GR. Similarly to our findings, Anav et al. (2011) reported a reduction of photosynthetic carbon uptake per day caused by $\left[\mathrm{O}_{3}\right]$ of about $22 \%$ in boreal and temperate forests. FACE fumigation experiment of enhanced $\mathrm{CO}_{2}$ and $\left[\mathrm{O}_{3}\right]$ on temperate forest dominated by Betula papyrifera Marsh. and Acer saccharum Marsh. in USA revealed reduction of cumulative net primary productivity of 9\% (Talhelm et al. 2014). However, Finco et al. (2017) estimated relatively low decreases in biomass production by $4-5 \%$ in Alpine larch forest caused by current $\left[\mathrm{O}_{3}\right]$ when compared to the pre-industrial era, even if the total ozone fluxes were generally high, up to $30-40 \mathrm{nmol} \mathrm{m} \mathrm{m}^{-2}$. This was due to relatively low portion of stomatal uptake by the larch forest representing only $15-16 \%$ of total $\mathrm{O}_{3}$ deposition flux into the forest. Similar growth reductions in stem increment of $6.6 \%$ and photosynthetic carbon uptake of $4-8 \%$ were observed in Switzerland (Braun et al. 2014) and eastern parts of USA (Yue \& Unger 2014), respectively, due to episodes of high tropospheric $\left[\mathrm{O}_{3}\right]$.

Norway spruce, one of the most common and important timber trees in Europe, was found to be an $\mathrm{O}_{3}$ sensitive tree species, showing substantial reductions in photosynthetic carbon uptake under elevated $\left[\mathrm{O}_{3}\right]$ (Wallin et al. 2002, Zapletal et al. 2011). For example, Subramanian et al. (2015) reported a decrease in carbon sequestration of spruce forest in Sweden by 4.3-15.5\% under ambient ozone conditions as compared to the preindustrial $\left[\mathrm{O}_{3}\right]$. This is consistent with our estimate of NEP reduction in mountain spruce forest of the temperate zone.

It should be noted, however, that there is a contrasting evidence of long-term $\mathrm{O}_{3}$ effects detected after several growing seasons. Since several research groups reported no negative effect of elevated $\left[\mathrm{O}_{3}\right]$ on carbon assimilation in forest ecosystems (Zak et al. 2011, Wang et al. 2016), we can hypothesize large acclimation capacity of tree species, including morphological (Riikonen et al. 2004, 2010) as well as biochemical adjustments (reviewed by Heath 2008). Recent studies have, however, shown that long-term exposure to elevated $\left[\mathrm{O}_{3}\right]$ may substantially modulate an acclimation of trees to other environmental factors like elevated temperature (Kivimäenpää et al. 2017) and/or elevated atmospheric $\mathrm{CO}_{2}$ concentration (Riikonen et al. 2010, Zak et al. 2011). The carbon sink strength in old forests could be thus reduced substantially or even disappear under the conditions of high $\left[\mathrm{O}_{3}\right]$, accelerating the impact of atmospheric $\mathrm{CO}_{2}$ on climate change. Precise estimates of $\mathrm{FsO}_{3}$ are 
thus needed for future predictions of ozone impacts on NEP of terrestrial ecosystems.

\section{Conclusions}

We have found that stomatal ozone flux model tracks diurnal changes in NEP more precisely that ozone concentration model does. NEP simulated at low, pre-industrial $\mathrm{FsO}_{3}\left(0.5 \mathrm{nmol} \mathrm{m}^{-2} \mathrm{~s}^{-1}\right)$ was higher by $24.8 \%$ as compared to NEP assessed at current $\mathrm{FsO}_{3}\left(8.32 \mathrm{nmol} \mathrm{m} \mathrm{m}^{-2} \mathrm{~s}^{-1}\right)$. Further increase in $\mathrm{FsO}_{3}$ (up to $17 \mathrm{nmol} \mathrm{m} \mathrm{s}^{-1}$ ) may lead to subsequent reduction in NEP by $14.1 \%$ in average as compared to current NEP values, but this reduction may change during the growing season. These results are in agreements with observations in other European coniferous forests. Relatively high site-specific variability in $\mathrm{O}_{3}$ ] effect of photosynthetic carbon uptake is likely caused by species-specific sensitivity of stomata to environmental drivers. Also a co-occurrence of other stress factors, particularly extreme temperatures and drought, leading to the changes in stomatal conductance and stomatal ozone flux, may influence a final response of trees to $\left[\mathrm{O}_{3}\right]$.

\section{Acknowledgement}

This work was supported by the Ministry of Education, Youth and Sports of the Czech Republic within the project "SustES Adaptation strategies for sustainable ecosystem services and food security under adverse environmental conditions" (CZ.02. 1.01/0.0/0.0/16_019/0000797).

\section{References}

Anav A, Menut L, Khvorostyanov D, Viovy $\mathrm{N}$ (2011). Impact of tropospheric ozone on the Euro-Mediterranean vegetation. Global Change Biology 17: 2342-2359. - doi: 10.1111/j.1365-2486. 2010.02387.x

Andersen CP (2003). Source-sink balance and carbon allocation below ground in plants exposed to ozone. New Phytologist 157: 213-228. doi: 10.1046/j.1469-8137.2003.00674.x

Aubinet M, Vesala T, Papale D (2012). Eddy Covariance. Springer, Dordrecht-Heidelberg-London-New York, pp. 438. - doi: 10.1007/978-94007-2351-1

Beniston M (2004). The 2003 heat wave in Europe: a shape of things to come? An analysis based on Swiss climatological data and model simulations. Geophysical Research Letters 31: L02202. - doi: 10.1029/2003GL018857

Braun S, Schindler C, Rihm B (2014). Growth losses in Swiss forests caused by ozone: Epidemiological data analysis of stem increment of Fagus sylvatica L. and Picea abies Karst. Environmental Pollution 192: 129-138. - doi: 10.1016/ j.envpol.2014.05.016

Cieslik S (2004). Ozone uptake by various surface types: a comparison between dose and exposure. Atmospheric Environment 38: 24092420. - doi: 10.1016/j.atmosenv.2003.10.063

Cooper OR, Parrish DD, Ziemke J, Balashov NV, Cupeiro M, Galbally IE, Gilge S, Horowitz L, Jensen NR, Lamarque J-F, Naik V, Oltmans SJ, Schwab J, Shindell DT, Thompson AM, Thouret
V, Wang Y, Zbinden RM (2014). Global distribution and trends of tropospheric ozone: an observation-based review. Elementa 2: 000029. doi: 10.12952/journal.elementa.000029

Emberson LD, Ashmore MR, Cambridge H, Simpson D, Tuovinen J-P (2000). Modelling stomatal ozone flux across Europe. Environmental Pollution 109: 403-414. - doi: 10.1016/S0269-7491(00) 00043-9

Fares S, Vargas R, Detto M, Goldstein AH, Karlik J, Paoletti E, Vitale M (2013). Tropospheric ozone reduces carbon assimilation in trees: estimates from analysis of continuous flux measurements. Global Change Biology 19: 24272443. - doi: 10.1111/gcb.12222

Fares S, Conte A, Chabbi A (2018). Ozone flux in plant ecosystems: new opportunities for longterm monitoring networks to deliver ozone-risk assessments. Environmental Science and Pollution Research 25: 8240-8248. - doi: 10.1007/s113 56-017-0352-0

Finco A, Marzuoli R, Chiesa M, Gerosa G (2017). Ozone risk assessment for an Alpine larch forest in two vegetative seasons with different approaches: comparison of POD1 and AOT40. Environmental Science and Pollution Research 24: 26238-26248. - doi: 10.1007/s11356-017-9301-1

Fuhrer J, Val Martin M, Mills G, Heald CL, Harmens $\mathrm{H}$, Hayes F, Sharps K, Bender J, Ashmore MR (2016). Current and future ozone risks to global terrestrial biodiversity and ecosystem processes. Ecology and Evolution 6: 8785-8799. doi: $10.1002 /$ ece3.2568

Heath RL (2008). Modification of the biochemical pathways of plants induced by ozone: what are the varied routes to change? Environmental Pollution 155: 453-463. - doi: 10.1016/j.envpol.20 08.03.010

Hoshika Y, Watanabe M, Carrari E, Paoletti E, Koike T (2018). Ozone-induced stomatal sluggishness changes stomatal parameters of Jarvis-type model in white birch and deciduous oak. Plant Biology 20: 20-28. - doi: 10.1111/plb.12 632

Juráň S, Pallozzi E, Guidolotti G, Fares S, Šigut L, Calfapietra C, Alivernini A, Savi F, Večeřová K, Křumal K, Večeřa Z, Urban O (2017). Fluxes of biogenic volatile organic compounds above temperate Norway spruce forest of the Czech Republic. Agricultural and Forest Meteorology 232: 500-513. - doi: 10.1016/j.agrformet.2016.10. 005

Karlsson PE (2012). Ozone impacts on carbon sequestration in northern and central European forests. IVL Report B 2065, IVL Swedish Environmental Research Institute, Gothenburg, Sweden, pp. 25. [online] URL: http://icpveg etation.ceh.ac.uk/events/documents/Karlsson. pdf

Kivimäenpää $M$, Sutinen S, Valolahti H, Häikiö E, Riikonen J, Kasurinen A, Ghimire RP, Holopainen JK, Holopainen T (2017). Warming and elevated ozone differently modify needle anatomy of Norway spruce (Picea abies) and scots pine (Pinus sylvestris). Canadian Journal of Forest Research 47: 488-499. doi: 10.1139/ cjfr-2016-0406

Klingberg J, Engardt M, Karlsson PE, Langner J, Pleijel H (2014). Declining ozone exposure of European vegetation. Biogeosciences 11: 52695283. - doi: 10.5194/bg-11-5269-2014
Kontunen-Soppela S, Ossipov V, Ossipova S, Oksanen $E$ (2007). Shift in birch leaf metabolome and carbon allocation during long-term open field ozone exposure. Global Change Biology 13: 1053-1067. - doi: 10.1111/j.1365-2486.2007.013 32.x

Matyssek R, Bytnerowicz A, Karlsson P-E, Paoletti E, Sanz M, Schaub M, Wieser G (2007). Promoting the $\mathrm{O}_{3}$ flux concept for European forest trees. Environmental Pollution 146: 587-607. doi: 10.1016/j.envpol.2006.11.011

Meehl GA, Covey C, Delworth T, Latif M, MCAvaney B, Mitchell JFB, Stouffer RJ, Taylor KE (2007). The WCRP CMIP3 multimodel dataset. Bulletin of the American Meteorological Society 88: 1383-1394. - doi: 10.1175/BAMS-88-9-1383 Musselman RC, Massman WJ (1998). Ozone flux to vegetation and its relationship to plant response and ambient air quality standards. Atmospheric Environment 33: 65-73. - doi: 10.1016/ S1352-2310(98)00127-7

Paoletti E, De Marco A, Beddows DCS, Harrison RM, Manning WJ (2014). Ozone levels in European and USA cities are increasing more than at rural sites, while peak values are decreasing. Environmental Pollution 192: 295-299. - doi: 10.1016/j.envpol.2014.04.040

Proietti C, Anav A, De Marco A (2016). A multisites analysis on the ozone effects on Gross Primary Production of European forests. Science of the Total Environment 556: 1-11. - doi: 10.1016/ j.scitotenv.2016.02.187

Reichstein M, Falge E, Baldocchi D, Papale D, Aubinet $M$, Berbigier P, Bernhofer C, Buchmann $\mathrm{N}$, Gilmanov T, Granier A, Grünwald T, Havránková K, llvesniemi H, Janous D, Knohl A, Laila T, Lohila A, Loustau D, Matteucci G, Meyers T, Miglietta F, Ourcival JM, Pumpanen J, Rambal S, Rotenberg E, Sanz M, Tenhunen J, Seufert G, Vaccari $F$ (2005). On the separation of net ecosystem exchange into assimilation and ecosystem respiration: review and improved algorithm. Global Change Biology 11: 1424-1439. doi: 10.1111/j.1365-2486.2005.001002.x

Riikonen J, Lindsberg MM, Holopainen T, Oksanen E, Lappi J, Peltonen P, Vaavouri E (2004). Silver birch and climate change: variable growth and carbon allocation responses to elevated concentration of carbon dioxide and ozone. Tree Physiology 24: 1227-1237. - doi: 10.1093/treephys/24.11.1227

Riikonen J, Percy KE, Kivimäenpää M, Kubiske ME, Nelson ND, Vapaavouri E, Karnosky DF (2010). Leaf size and surface characteristics of Betula papyrifera exposed to elevated $\mathrm{CO}_{2}$ and $\mathrm{O}_{3}$. Environmental Pollution 158: 1029-1035. doi: 10.1016/j.envpol.2009.07.034

Royal Society (2008). Ground-level ozone in the $21^{\text {st }}$ century: future trends, impacts and policy implications. The Royal Society, London, UK, pp. 132.

Samuelson LJ (1994). Ozone-exposure responses of black cherry and red maple seedlings. Environmental and Experimental Botany 34: 355-362. - doi: 10.1016/0098-8472(94)900175

Sicard P, Augustaitis A, Belyazid S, Calfapietra C, DeMarco A, Fenn M, Grulke N, He S, Matyssek R, Serengil Y, Wieser G, Paoletti E (2016). Global topics and novel approaches in the study of air pollution, climate change and forest ecosys- 
tems. Environmental Pollution 213: 977-987. doi: 10.1016/j.envpol.2016.01.075

Sitch S, Cox PM, Collins WJ, Huntingford C (2007). Indirect radiative forcing of climate change through ozone effects on the land-carbon sink. Nature 448: 791-794. - doi: 10.1038/na ture06059

Skärby L, Ro-Poulsen H, Wellburn FAM, Sheppard LJ (1998). Impacts of ozone on forests: a European perspective. New Phytologist 139: 109-122. - doi: 10.1046/j.1469-8137.1998.00184.x Solberg S, Hov O, Sovde A, Isaksen ISA, Coddeville $\mathrm{P}$, De Backer H, Forster C, Orsolini Y, Uhse K (2008). European surface ozone in the extreme summer 2003. Journal of Geophysical Research Atmospheres 113: D07307. - doi: 10.1029/2007JD 009098

Subramanian N, Karlsson PE, Bergh J, Nilsson U (2015). Impact of ozone on sequestration of carbon by Swedish forests under a changing climate: a modeling study. Forest Science 61: 445457. - doi: 10.5849/forsci.14-026

Sun G, McLaughlin SB, Porter JH, Uddling J, Mulholland PJ, Adams MB, Pederson N (2012). Interactive influences of ozone and climate on streamflow of forested watersheds. Global Change Biology 18: 3395-3409. - doi: 10.1111/j.13 65-2486.2012.02787.x

Talhelm AF, Pregitzer KS, Kubiske ME, Zak DR, Campany CE, Burton AJ, Dickson RE, Hendrey GR, Isebrands JG, Lewin KF, Nagy J, Karnosky DF (2014). Elevated carbon dioxide and ozone alter productivity and ecosystem carbon content in northern temperate forests. Global Change Biology 20: 2492-2504. - doi: 10.1111/gcb. 12564

Urban O, Klem K, Ač A, Havránková K, Holišová P, Navrátil M, Zitová M, Kozlová K, Pokorný R, Šprtová $M$, Tomášková I, Špunda V, Grace J (2012). Impact of clear and cloudy sky conditions on the vertical distribution of photosynthetic $\mathrm{CO}_{2}$ uptake within a spruce canopy. Functional Ecology 26: 46-55. - doi: 10.1111/j.13652435.2011.01934.x

Verryckt LT, Op De Beeck M, Neirynck J, Gielen
B, Roland M, Janssens IA (2017). No impact of tropospheric ozone on the gross primary productivity of a Belgian pine forest. Biogeosciences 14: 1839-1855. - doi: 10.5194/bg-14-18392017

Wallin G, Karlsson PE, Selldén G, Ottosson S, Medin EL, Pleijel H, Skärby L (2002). Impact of four years exposure to different levels of ozone, phosphorus and drought on chlorophyll, mineral nutrients, and stem volume of Norway spruce, Picea abies. Physiologia Plantarum 114: 192-206. - doi: 10.1034/j.1399-3054.20 02.1140205.x

Wang B, Shugart HH, Shuman JK, Lerdau MT (2016). Forests and ozone: productivity, carbon storage, and feedbacks. Scientific Reports 6: 22133. - doi: 10.1038/srep22133

Wittig VE, Ainsworth EA, Naidu SL, Karnosky DF, Long SP (2009). Quantifying the impact of current and future tropospheric ozone on tree biomass, growth, physiology and biochemistry: a quantitative meta-analysis. Global Change $\mathrm{Bi}-$ ology 15: 396-424. - doi: 10.1111/j.1365-2486.20 08.01774.x

Wood SN (2017). Generalized additive models: an introduction with $\mathrm{R}$ ( $2^{\text {nd }}$ edn). Chapman and Hall/CRC, New York, USA, pp. 476. [online] URL: http://www.taylorfrancis.com/books/9781 498728348

Young PJ, Archibald AT, Bowman KW, Lamarque JF, Naik V, Stevenson DS, Tilmes S, Voulgarakis A, Wild O, Bergmann D, Cameron-Smith P, Cionni I, Collins WJ, Dalsren SB, Doherty RM, Eyring V, Faluvegi G, Horowitz LW, Josse B, Lee YH, MacKenzie IA, Nagashima T, Plummer DA, Righi $M$, Rumbold ST, Skeie RB, Shindell DT, Strode SA, Sudo K, Szopa S, Zeng G (2013). Preindustrial to end $21^{\text {st }}$ century projections of tropospheric ozone from the Atmospheric Chemistry and Climate Model Intercomparison Project (ACCMIP). Atmospheric Chemistry and Physics 13: 2063-2090. - doi: 10.5194/acp-13-2063-2013 Yue X, Keenan TF, Munger W, Unger N (2016). Limited effect of ozone reductions on the 20year photosynthesis trend at Harvard forest.
Global Change Biology 22: 3750-3759. - doi: 10.1111/gcb.13300

Yue X, Unger N (2014). Ozone vegetation damage effects on gross primary productivity in the United States. Atmospheric Chemistry and Physics 14: 9137-9153. - doi: 10.5194/acp-14-91372014

Zak DR, Pregitzer KS, Kubiske ME, Burton AJ (2011). Forest productivity under elevated $\mathrm{CO}_{2}$ and $\mathrm{O}_{3}$ : positive feedbacks to soil $\mathrm{N}$ cycling sustain decade-long net primary productivity enhancement by $\mathrm{CO}_{2}$. Ecology Letters 14: 12201226. - doi: 10.1111/j.1461-0248.2011.01692.x

Zapletal M, Cudlín P, Chroust P, Urban O, Pokorný $R$, Edwards-Jonášová $M$, Czerný $R$, Janouš $D$, Taufarová K, Večeřa Z, Mikuška P, Paoletti E (2011). Ozone flux over a Norway spruce forest and correlation with net ecosystem production. Environmental Pollution 159: 1024-1034. doi: 10.1016/j.envpol.2010.11.037

Zapletal M, Pretel J, Chroust P, Cudlín P, Edwards-Jonášová $M$, Urban $\mathrm{O}$, Pokorný $\mathrm{R}, \mathrm{Cz}$ erný R, Hůnová I I (2012). The influence of climate change on stomatal ozone flux to a mountain Norway spruce forest. Environmental Pollution 169: 267-273. - doi: 10.1016/j.envpol.2012.05.008

Zona D, Gioli B, Fares S, De Groote T, Pilegaard K, Ibrom A, Ceulemans R (2014). Environmental controls on ozone fluxes in a poplar plantation in Western Europe. Environmental Pollution 184: 201-210. - doi: 10.1016/j.envpol.2013.08.032

\section{Supplementary Material}

Fig. S1 - Diurnal courses of modelled stomatal ozone flux $\left(\mathrm{FsO}_{3}\right)$ in Norway spruce forest during the investigated period of May 28 - September 30, 2009.

Fig. S2 - Principal component analysis revealing dependencies of environmental variables among each other.

Link: Juran_2805@supploo1.pdf 